\title{
The training of Albanian Public Administration: An Analysis of Training Policies and Their Impact in the Professional Development of Civil Servants
}

\author{
Teuta Nunaj \\ Ph.D. Candidate, Lecturer at Marin Barlety University, Tirana, Albania \\ Email: teuta.nunaj@gmail.com
}

\author{
Doi:10.5901/jesr.2016.v6n3p149
}

\begin{abstract}
This study does analyse the training policies that apply for civil servants in the Public Administration and how this training process has an impact in the professional development of civil services in Albania. The research question is: What effects does the training have in the development of Human Resources in the public administration in Albania? The data are obtained from sevent elite interviews and four ministries randomly selected through questionnaires, with $n=179$ civil servants. By using qualitative and quantitative method is found that the training has directly a significant and positive impact in the professional development of Albanian civil servants. Doing the training is a condition for the development of civil servants on public administration. The civil servants do have a growing request for effective and appropriate training. However, there are the responsible institutions for the training (ASPA and the ministries) that should increase also the level of collaboration, to obtain better results from training.
\end{abstract}

Keywords: Training policies, The development of Human Resources, Public Administration.

\section{Introduction}

In the frame of the reform, the public administration has made a lot of changes. One of the main element is the development of the Human Resources (HR). One of the European challenges of Albania is the reform in public administration, but, that cannot be successful without the development of HR. The civil servants are a key resource and a capital in public administration, and their professionalism has a direct impact in the success of the reform. To be more professional, the HR need to be trained and for this reason the public investment for the development of HR for training, should be a priority.

This study is divided in three parts. The first part of the study will explain various authors" points of view in connection with the importance and the role that the training has in the professional development of HR. The second part, will explicate the training policies that do apply in Albania and the collaboration between the responsable institution for the training of civil servants. The thrid part will be followed by the analysis of the data which is collected through elite interviews and questionnaires obtained from civil servants in the Ministry of Education and Sports (MES), in the Ministry of Transport and Infrastructure (MTI), in the Ministry of Youth and Social Welfare (MYSW) and in the Ministry of Agriculture, Rural Development and Water (MARDW). The hypothesis intended to be supported is the following: The training is a necessary neccesity for development of civil servants in the Albanian public administration.

\subsection{Objectives of the research:}

1. To explicate the planning process of the training from responsible institutions.

2. To analyze the collaboration between Albanian School of Public Administration (ASPA) and ministries for the development of the trainings of civil servants.

3. To address the connection between the criteria that the institution establishes for training and the needs that civil servants have for the training.

4. To evaluate the impact of the training programmes in the professional development of civil servants.

5. To analyze the feedback of public servants for the effectiveness of the training that they have done. 


\subsection{Study importance}

Nowadays, the impact of the training in the development of Human Resources (HR) makes an important study field in the Albanian public administration. However, such studies are not easily found in Albania, so the study is important to help to fill the gap. Albania does have 103 years that has created its public administration; it has a university and a public administration school, but it does not have a scientific collaboration between the Public Administration and universities.

\subsection{Methodology}

The methodology applied in this study is analytical and based on primary and secondary resources. As first resource are the empirical data and surveys. As far as empirical data is concerned, they are obtained through elite interviews, as part of semi-structured interviews with purposeful sample, and as far as structured interviews through surveys is concerened with civil servants as random sample in fourth ministries cited. The secondary research deals with theoretical studies on the training and the interior documents that are used from the public administration for training.

The interpretivist approach is applied through the datas taken from elite interviews coming from middle and higher officials from ASPA, from the HR sector in ministries cited and with the chiefs of the departments of public administration in two public universities in Albania. These officials are identified on the basis of their position they have in their institutions.

From 9 elite interviews, 3 were conducted between e-mails, 1 was done by writing and 5 one were done face to face.

The period that is analyzed is January - December 2014. The data is obtained from May until October 2015. 179 questionnaires were filled and hard copies are available. Qualitative methods and SPSS Statistics are used for data processing. The population is this study includes the factice civil servants that are employees from four representative ministries randomly selected and they are: MES 84 civil servants, MTI 70 civil servants, MYSW 72 civil servants and MARDW 85 civil servants, in total there are 311 civil servants. The sample of 179 civil servants gives us a confidence level of $95 \%$ with a margin of error of $5 \%$.

\section{Literature Review}

Albania has still a need to examine and take new scientific knowledge on how the public administration should function in order to be effective. Irwin L. Goldstein said that training is "the acquisition of skills, concepts, or attitudes that results in improved performance in an on-the-job environment" (Goldstein, 1980:229). According to Robins DeCenzo, "The training of the employers is an education experience, and the goal is to realise a relative change of the employers, to improving their performance skills at work" (DeCenzo, 2011:267). Training is important for the organisation, be it private or public. So, "at the organizational level, a traditional training program designed to teach a skill that has direct and current applications in the organization often can be evaluated in terms of measures of an increase in operating efficiency" (Olslzfski, Crrtchirz, 2001:499). And "the traditional training format is excellent for teaching or improving technical skills, as well as for informing participants about current thinking in a discipline" (Same source, p. 449).

In order for employers to be professionally developed, the criteria are necessary: to be provided during training with the necessary competencies that it needs to grow professionally; to be encouraged to develop individual skills and teamwork, in order to achieve the objectives; to affect the growth and strengthening of his intellectual capacity with modern knowledge, to prepare for the challenges and demands of the continuous market; and to be helped directly to increase motivation and productivity at work of the civil servants. Director of ASPA, F. Demneri (personal communication, 30 December 2014) confirms that "the training is directly related to the development of human resources. Training is directly related to improving performance at work, professional development as well as career development [the civil servants]". So, is important that "an individual's education and training must necessarily transcend experience as a primary promotional consideration" (Daniello, Laubsch, 2008:6)

In the report "Public Service Training System in OECD Countries - SIGMA [Support for Improvement in Governance and Management] papers no. 16 that OECD has published in 1997, it emphasizes the importance of training for the public administration employees: "A good training system is crucial for any organization to develop and retain high professional standards of conduct and performance for its staff" (OECD, 1997:3).

A Final Report establishes several important elements that should be included in the training programs: "The program or training curriculum shall enhance the student's competencies, values, knowledge, and skills to act ethically, 
equitably, effectively and with efficiency: Subject to the mission of the program, they should include: (i) The Management of Public Service Organizations; (ii) Improvement of Public Sector Processes; (iii) Leadership in the Public Sector; (iv) The Application of Quantitative and Qualitative Techniques of Analysis; (v) Understanding Public Policy and the Organizational Environment" (United Nations Department of Economic and Social Affairs /International Association of Schools and Institutes of Administration [UNDESA/IASIA] 2008:9,10).

According to The European Commission and SIGMA "the training and development of civil servants as key instruments for the development of administrative capacity in pre-accession states [as Albania]. Civil service training is directly linked to effectiveness as a central European principle of administration" (Meyer-Sahling, 2012:60).

\section{The Development of Training in Albania}

At the end of the 90's, which is the first decade of the democracy in Albania, the management of HR is almost unknown and so is the training of civil servants in the Albanian public administration. In the beginning of the new Millenium, when the development of the country has received news dynamism, when the technology was spreading significantly to public functions, when the trade was looking for quality public services, when the criteria to work in civil service was growing and after the counseling from European experts to the public, it came as the institutional needs administration the development of the training for civil servants.

The realisation of public administration reform in Albania can not be understood without the capacity building and the development of HR. But, if the civil servants want to increase professionally, it is necessary to continue to be qualified and to be prepared for their duties. The civil servants do have a need to be trained in continuity and for this reason, the government has decided to create the Training Institute of Public Administration by the Decree of the Council of Ministers No 315, dated 23.03.2000. This decree states: "Establishment of the Training Institute of Public Administration (the Institute), as an institution under the supervision of the Council of Ministers" (Center of the Official Publishing [COP], 2000:883). The mission of TIPA was: "To support the improvement and reform of a sustainable and professional civil service through qualitative and comprehensive training and development" (Cited from Mitrushi, n.d.:4).

The Albanian government "have given a special attention to the increase of capacity of civil servants of public administration, by their training" (Albanian Government, 2008:12). But, after 3 years that TIPA was created, it "began operation regularly and to organise training for the civil servants of public administration" (Same source, p.12). At the beginning the principal problem for TIPA is the need for the qualified staff, bur after some years it appeared as another important problem, that was the collaboration between TIP and the ministries. In the annual report in 2006 that was prepared from DoPA, is emphasized the demand of TIPA that "ministries should be more active in the training process of civil servants and in the end of the training it is necessary to evaluate the effects of training at public servants. Ministries should exercise more control and to be more demanding to them, in term of active attendance at different training" (Council of Ministers, n.d.:14).

The Council of Ministers by Decree No. 220, dated 23.06.2013 decided: "to create and to function the Albanian School of Public Administration (ASPA)" (COP, 2013:2347). "Since April 2013, the ASPA is carrying out several trainings according to the training schedule. In this regard and in terms of training of civil servants, the ASPA has carried out and continued the training activities during the period September 2013 - April 2014, in accordance with its training schedule supported by the foreseen budget and in cooperation with the projects supported by the European Union (PPF and SMEI III), etc." (Ministry of the European of Integration [MEI], 2014:19). But in 2014 "ASPA is responsible for civil servants training. The quality and quantity of training has increased, but ASPA's budget is insufficient for the increased number of civil servants in need of training. The new performance appraisal system is not yet used widely." (European Commission, 2015:10).

In difference with TIPA that was limited at civil servants and at training schedule that was approved by DoPA, "ASPA have administrative autonomy and autonomy in determination in curriculum and training schedule. Its aim is to contribute in professional formation of civil servants of public administration... (Albanian Parliament, 2013:.2347) and at the same time, "ASPA offers programs for profound and continuing formation, in this base the civil servants from all categories of work have the possibility to continue the training, and every native or foreign individual that is out of public service" (Council of Ministers, 2014:2347). As a conclusion, it can be said that between training, ASPA have an important role for raising public administration capacities. Training, not only in theory or in level of round-table discussion, but practically, it is needed to see and after to function as a necessary and basic instrument for raising Albanian professional public administration capacities.

ASPA for the first time stated "Action Plan includes the digitalization of its education material, putting it on a digital 
platform and setting up an eLearning system. The use of the Information technology in the training system is likely to facilitate the sustainability as ASPA's training" (ASPA, 2014, paragraph 3). After that, ASPA "on the 29th of October present the new platform [of electronic learning] and [the first group of] developers of training were provided with necessary technical methods/instructions for the preparation of these training" (ASPA, 2015, paragraph 3).

\section{Analysis of Empirical Data}

In this third part of the essay, will be continued by the elaboration in SPSS Statistics of the data collected in the field by survey.

The questionnaire addressed to complement civil servants and heads of low and medium executive category levels. Graph 1 provides data on the respondent to share in percentage by gender for the three ministries taken for analysis. In total, $32 \%$ of the respondents were males and $68 \%$ females. Figure 1 provides data on the respondent to share the percentage by gender and in Figure 2 by age groups.

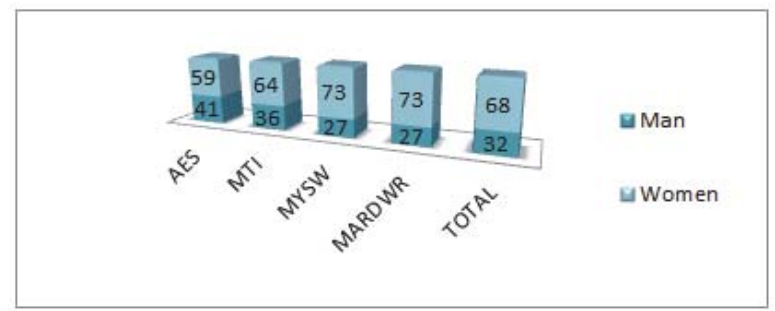

Figure 1: Surveyors by gender (\%)

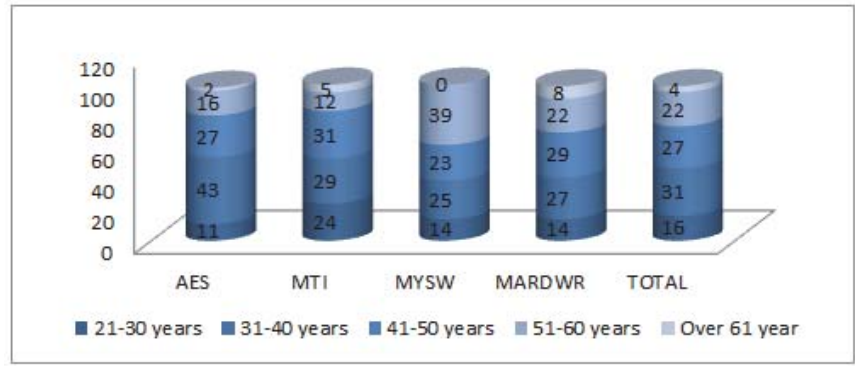

Figure 2: Surveyors by ages

In table 1 provides data on civil servants according to their status at work for every ministry.

Table 1: The status at work of employees

\begin{tabular}{|c|c|c|c|c|}
\hline \multirow{2}{*}{ Institution } & \multicolumn{2}{|c|}{ Civil servants, confirmed } & \multicolumn{2}{c|}{ Civil servants, on probation period } \\
\cline { 2 - 5 } & No. & $\%$ & No. & $\%$ \\
\hline MES & 41 & $93 \%$ & 3 & $7 \%$ \\
\hline MTI & 36 & $86 \%$ & 6 & $14 \%$ \\
\hline MYSW & 35 & $80 \%$ & 9 & $20 \%$ \\
\hline MARDWR & 42 & $86 \%$ & 7 & $14 \%$ \\
\hline In total & 154 & $\mathbf{8 6} \%$ & $\mathbf{2 5}$ & $14 \%$ \\
\hline
\end{tabular}

The data in the field we can see that we have $86 \%$ civil servants confirmed and $14 \%$ civil servants on probation period. And about the position in the work, there are 136 executive civil servants or $76 \%$ of total and 43 managers or $24 \%$ of total. 


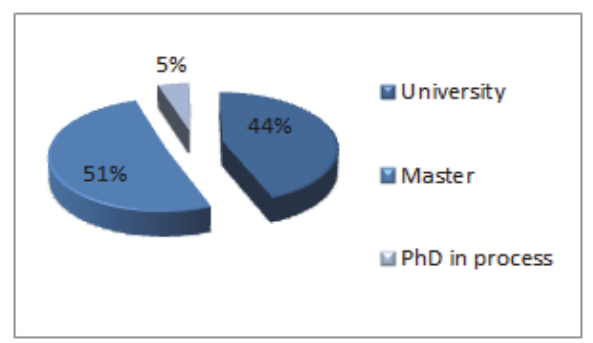

Figure 3: Level of education (\%)

\begin{tabular}{|ll|c|c|}
\multicolumn{2}{c}{ Correlations } \\
\hline \multicolumn{1}{|c|}{ Pearson Correlation } & Gender & Position in work \\
\hline Gender & Sig. (2-tailed) & 1 & $-.197^{* *}$ \\
& $\mathrm{~N}$ & & .008 \\
\multirow{3}{*}{ Position in work } & Pearson Correlation & $-.197^{\text {** }}$ & 179 \\
& Sig. (2-tailed) & .008 & 1 \\
& $\mathrm{~N}$ & 179 & 179 \\
\hline ** Correlation is significant at the 0.01 level (2-tailed) & & \\
\hline
\end{tabular}

As we can see, the correlation between Gender and the Position in work (Executive civil servants or managers) is significant and weak negative.

\begin{tabular}{|ll|c|c|}
\multicolumn{2}{c|}{ Correlations } \\
\hline \multicolumn{2}{|c|}{ Ages } & Ages & Status at work \\
\hline \multirow{3}{*}{ Status at work } & Pearson Correlation & 1 & $-.249^{* *}$ \\
& Sig. (2-tailed) & & .001 \\
& N & 179 & 179 \\
& Pearson Correlation & $-.249^{* *}$ & 1 \\
& Sig. (2-tailed) & .001 & 179 \\
\hline
\end{tabular}

The correlation between Ages and the Status at work is significant and weak negative. Pearson correlation coefficient $r$ is -.249 and this is statistically significant $p<0.05(0.01<0.05)$.

\begin{tabular}{|ll|c|c|}
\hline \multicolumn{2}{c|}{ Correlations } \\
\hline Level of Education & Pearson Correlation & Level of education & Status at work \\
& Sig. (2-tailed) & 1 & $.160^{*}$ \\
& $\mathrm{~N}$ & & .032 \\
Status at work & Pearson Correlation & 179 & 179 \\
& Sig. (2-tailed) & $.160^{*}$ & 1 \\
& $\mathrm{~N}$ & .032 & 179 \\
\hline
\end{tabular}

*. Correlation is significant at the 0.05 level (2-tailed).

The correlation between Level of Education and the Status at work is significant and weak positive. Pearson correlation coefficient $r$ is .160 and this is statistically significant $p<0.05(0.032<0.05)$. 


\subsection{The criteria for training}

The Council of Ministers by Decree No. 138, dated 23.03.2014 in "The rules of organisation and the function of Albanian School of Public Administration and the training of civil servants" decided that the civil servants have the possibility to do training in ASPA "... with order of direct superior, on base of the evaluation of the results at work" (Council of Ministers, 2014:5). For the year 2014, head of Human Resource Office on MTI, E. Fusha (personal communication, 23 July 2015) was able to confim: "as the new status of civil servants entered in aplication on 26 February 2014, ASPA [for the year 2014] has done the obligatory training for all civil servants that were on probation period". So, for the year 2014, 122 civil servents or $68 \%$ of total have doing at least one training and 57 civil servents or $32 \%$ of total, or one in three civil servents haven't doing any training for all the year.

General Director of Support Services on MTI, A. Kaja (personal communication, 27 July 2015) declares on the basis of law that "the needs for training arised during the process of evalutation of employers and defined from the reporting officer on collaboration with the servants". While the Specialist of Human Resource on MYSW, A. Kodra (personal communication, 23 July 2015) declaration is that the "Head [of sector] that decides which of the civil servants need training. The civil servants did the request for training, after that they take the notification for the training from HR". But, do they respect the law?

To take the opinion from respondents for the question: Which are the indicator to determines the need for training, in the question there were some ready alternatives. The respondents had the possibility to choose only one answer. At the some time, they had the possibility to choose the alternative "Other" and give their opinions. The data that was collected in the field are reflected in table 2 :

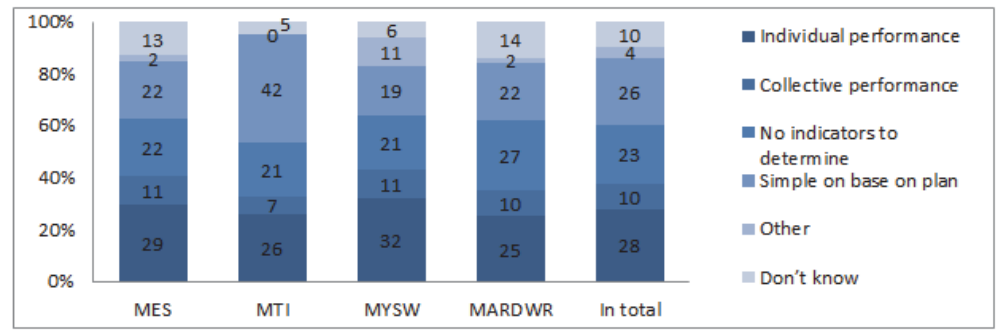

Figure 4: The indicators of the need for training (\%)

In the alternative "Other" the indicators that they have given as a need for training are:

a) Understanding/Decision on supervisor.

b) The profile of the work and the evaluation on their work.

In this question it is not set that the needs for training was determined by the evaluation of the work of civil servants throughout the evaluation reports. This was chosen on mood to test their knowledge. Only one of the respondents has determined "the evaluation of work" as a element that determined the need for training. This indicates two things: the first, the employers have insufficient information and secondly, their supervisor do not inform them for this. But, for this reason, with a lot of probability this part of the law has a little chance to be implemented. Disturbing is the fact that for $26 \%$ of respondents in the training are "simple on base of plan". All these results tell that there is a lot of work to be done for the effectivity of the training.

\subsection{The value of training}

Before analyzing directly the opinion of respondents for the value of the training, in two different figures will be presented the data for the valuation before and after training. 


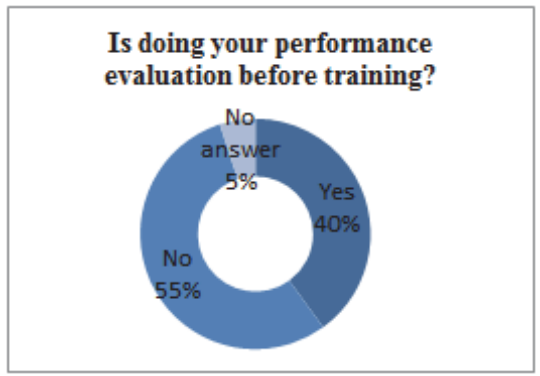

Figure 5: The evaluation before training (\%)

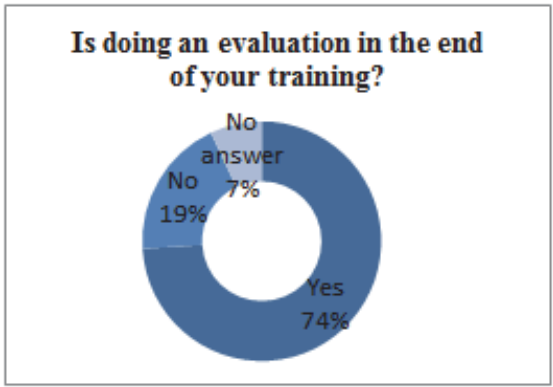

Figure 6: The evaluation in the end of training (\%)

On Decree of the Council of Ministers No. 138 is defined that: "For training ... [doing from ASPA], the civil servants subjected the test at the end of the training. The training considered finishing with success if the civil servant take at least 50\% of the points in the test" (Council of Ministers, 2014:6). A. Hoti (personal communication, 30 December 2014) confirmed that "ASPA doing the test the end of the training, as a instrument to value the training and how the servants have benefited effectively from the training". While from the results from figures $74 \%$ declare that at the end of training do the evalutation, but $4 \%$ of respondents declaration that in the end of training they do the evaluation of the process, but, not in every case. $19 \%$ of respondents declared that at the end of training they did not do the evaluation of the process. Failure to carry out the evaluation is not only a lawlessness, but is something bad for the civil servants because it does not measure the knowledge of the trained civil servans, if they have benefited from the training that was done. This brings the reduction of the value of the training, the responsibility of trainers, the motivation and the predisposition of the civil servants to benefit on maximum lore and knowledge from the training.

Meanwhile $55 \%$ of the respondents declared that they did not do the measuring of performance before the training, and $19 \%$ of respondents declared that in the end of the training, they did not do the evaluation of the process. This tells in direct link a lack of seriousness and professional commitment in the training process. We can prove this from the feedback of the respondents, when $26 \%$ of respondents declared that the training are "simple on the basis of the plan".

Correlations

\begin{tabular}{|c|c|c|}
\hline & $\begin{array}{c}\text { Which is your opinion for the trainings } \\
\text { programs doing from ASPA? }\end{array}$ & $\begin{array}{l}\text { How efficient is the training for } \\
\text { your professional development? }\end{array}$ \\
\hline $\begin{array}{l}\text { Which is your opinion for } \\
\text { trainings programs doing from } \\
\text { ASPA? }\end{array}$ & $\begin{array}{l}1 \\
179 \\
.724^{\text {t* }} \\
.000 \\
179\end{array}$ & $\begin{array}{c}.724^{* *} \\
.000 \\
179 \\
1 \\
179\end{array}$ \\
\hline
\end{tabular}

**. Correlation is significant at the 0.01 level (2-tailed). 
The correlation between Opinions for trainings program and Training efficiency is significant and strong positive. The Pearson correlation coefficient $r$ is .724 and this is statistically significant $p<0.0005(0.000<0.0005)$.

\section{Correlations}

\begin{tabular}{|l|c|c|}
\hline & $\begin{array}{c}\text { Which are the indicators to } \\
\text { determine the need for training? }\end{array}$ & $\begin{array}{c}\text { How efficient is the training for your } \\
\text { professional development? }\end{array}$ \\
\hline $\begin{array}{l}\text { Which are the indicators to Pearson Correlation } \\
\text { determine the need for training? Sig. (2-tailed) }\end{array}$ & 1 & $.403^{\text {** }}$ \\
& & .000 \\
How efficient is the training for Pearson Correlation & 179 & 179 \\
your professional development? Sig. (2-tailed) & $.403^{* *}$ & 1 \\
& .000 & 179 \\
\hline
\end{tabular}

${ }^{*}$. Correlation is significant at the 0.01 level (2-tailed).

The correlation between the indicator to determine the need for training and Training efficiency is significant and average positive. The Pearson correlation coefficient $r$ is .403 and this is statistically significant $p<0.0005(0.000<0.0005)$.

The research hypothesis is: there is a relation between the presence in training and the perception of training as an indicator for the professional development of civil servants.

The null hypothesis is: there is not a relation between the presence in training and the perception of training as an indicator for the professional development of civil servants.

\section{Chi-Square Tests, Phi and Cramer's Vare both tests}

Chi-Square Tests

\begin{tabular}{|l|c|c|c|}
\hline & Value & Df & Asymp. Sig. (2-sided) \\
\hline Pearson Chi-Square & $32.234^{\mathrm{a}}$ & 2 & .000 \\
Likelihood Ratio & 30.388 & 2 & .000 \\
Linear-by-Linear Association & 24.243 & 1 & .000 \\
N of Valid Cases & 179 & & \\
\hline
\end{tabular}

a. 2 cells (33.3\%) have expected count less than 5 . The minimum expected count is 2.23 .

The sample size requirement for the chi-square test of independence is satisfied.

Symmetric Measures

\begin{tabular}{|ll|c|c|}
\hline & & Value & Approx. Sig. \\
\hline Nominal by Nominal & Phi & .424 & .000 \\
N of Valid Cases & Cramer's V & .424 & .000 \\
\hline
\end{tabular}

a. Not assuming the null hypothesis.

b. Using the asymptotic standard error assuming the null hypothesis.

As we can see here Chi-square $(2)=32.234, p=.000$, less than the alpha level of significance of 0.05 . The null hypothesis is not accepted. So, there is a statistically significant relation between the presence in training and the perception of training as an indicator for the professional development of civil servants.

And we can see that the strength of relation between the variables is moderate (.424).

The research hypothesis is: there is a relation between the participation in training and the effectiveness of training as an indicator for the professional development of civil servants.

The null hypothesis is: there is not a relation between the participation in training and the effectiveness of training as an indicator for the professional development of civil servants. 


\section{Chi-Square Tests, Phi and Cramer's Vare both tests}

\begin{tabular}{|l|c|c|c|}
\hline \multicolumn{3}{c|}{ Chi-Square Tests } \\
\hline Pearson Chi-Square & Value & Df & Asymp. Sig. (2-sided) \\
Likelihood Ratio & $55.014^{\mathrm{a}}$ & 4 & .000 \\
Linear-by-Linear Association & 59.155 & 4 & .000 \\
N of Valid Cases & 45.523 & 1 & .000 \\
\hline
\end{tabular}

a. 4 cells $(40.0 \%)$ have expected count less than 5 . The minimum expected count is 1.91 .

The sample size requirement for the chi-square test of independence is satisfied.

Symmetric Measures

\begin{tabular}{|ll|c|c|}
\hline & & Value & Approx. Sig. \\
\hline Nominal by Nominal & Phi & .554 & .000 \\
N of Valid Cases & Cramer's V & .554 & .000 \\
\hline
\end{tabular}

a. Not assuming the null hypothesis.

b. Using the asymptotic standard error assuming the null hypothesis.

As we can see here Chi-square $(2)=55.014, p=.000$, less than the alpha level of significance of 0.05 . The null hypothesis is not accepted. So, there is a statistically significant relation between the participation in training and the effectiveness of training as an indicator for the professional development of civil servants.

And we can see that the strength of the relation between the variables is moderate (.554).

To answer the research question, now we will say that the training has significant and important effects in the development of HR in the public administration in Albania.

The research hypothesis that the training is necessary for the development of civil servants in the Albanian Public Administration is supported by this analysis.

\section{Conclusion}

Meanwhile Albania has 12 years that has began the training of civil servants in the public administration, and it has managed to create its experience and to do this process by the institutions created for training. However, there is a lot of work to be done, so that we can have the possibility to take proper results, that training will be efficient, helpful for the growth of the capacity of HR and for the development of administration.

During the empirical analysis, important problems came out that do have a need for improvement. For the training criterias the results are: before the training the evaluation of their performance is not done every time in order to see the need they have for training; meanwhile the law establishes that the news for training are established, only one of respondents have determined "the evaluation of the work" as a element that determined the need for training. Disturbing is the fact that for $26 \%$ of respondents the training are "simple on the basis of the plan". All these results do demonstrate that a lot of work needs to be done for the effctiveness of the training.

For the value that the training has, the results are: $19 \%$ of respondents declare that in the end of the training did not do the evaluation of the process. Meanwhile, for the law it is a duty to do this process. This brings the reduction of the value of the training, the responsibility of the trainers, the motivation and the predisposition of the civil servants to benefit on maximum lore and knowledge from the training; the respondents value the training as a valuable element for the profesional development.

The correlation between Opinions for trainings program and Training efficiency is significant and strongly positive. The correlation between the indicator to determine the need for training and Training efficiency is significant and average positive. So, if institutions can collaborate with civil servants can help to project necessary programs for them and in this mood can help civil servants in their professional development.

In the conclusion, the preceding analysis gives the answer of the research question that was submitted in the beginning of the study and at the same time has proven the hypothesis that the training has a basic role in the development of professional capacity of HR. Doing the training is a condition for the development of civil servants on 
public administration and they have a growing request for effective and appropriate training. But, it is the responsible institutions for the training (ASPA and the ministries) which should grow the level of collaboration not only between them, but and with the universities, to enable better results from training.

\section{References}

Albanian Goverment. (2008). Raport of Albanian Goverment for civil service 2003. Available: http://dap.gov.al//images/tedhenainst/websitedap/dokumenta\%20strategjike/raporte\%20vjetor\%20Dap/raportivjetor2003.pdf

Albanian School of Public Administration, (2014). Designing innovative training methods for the Albanian public administration. Tirana, Albania: ASPA. Available: http://aspa.gov.al/en/publikime1/77-training-on-legislative-gap-analysis-lga-2

Albanian School of Public Administration, (2015). Welcome to ASPA e-Learning. Tirana, Albania: ASPA. Available: http://aspa.gov.al/al/publikime1/105-aspa-prezanton-platformen-e-trajnimit-on-line

Center of the Official Publishing. (2000). The Decree of the Council of Ministers No 315, dated 23.03.2000 For establishment of the Training Institute of Public Administration and training of civil servants: July, Official Journal of Republic of Albania, 18. Available: http://www.legjislacioni.gov.al/sites/defaultffiles/18-2000.pdf.

Center of the Official Publishing. (2013). The Decree of the Council of Ministers No 220, dated 13.2.2013 For establishment and the function of Albanian School of Public Administration and training of civil servants of public administration: April 16, Official Journal of Republic of Albania, 54. Available: http://qbz.gov.al/botime/fletore_zyrtare/2013/PDF-2013/54-2013.pdf

Council of Ministers. (2014). Decree No 138, The rules of organisation and the function of Albanian School of Public Administration and the training of civil servants; March 12. Available: http://www.aspa.gov.al/images/howtoAlbania/Rregullat\%20e\%20organizimi0001.pdf

Council of Ministers, Department of Public Administration. (n.d.) Annual report: 2006. Available: http://dap.gov.al/dokumenta/raportetvjetore/68-raporti-vjetor-dap-2006

DeCenzo, R. (2011). The recruitment of staff and the management of HR. In Bases of management: Concepts and basic applications (pp. 246-289). Tirana, Albania: UET Press.

European Commission, (2015). Commission staff working document Albania 2015 Report, 10 Novembre, SWD (2015) 213 final. Available: http://www.integrimi.gov.al/files/documents_files/20151110_report_albania.pdf

Goldstein, I. L. (1980). Training in Work Organizations, Annual Review of Psychology, 31, pp. 229-272.

Meyer-Sahling, J. (2012). Civil Service Professionalisation in the Western Balkans, SIGMA Papers, 48. OECD Publishing. Available: http://dx.doi.org/10.1787/5k4c42jrmp35-en

Ministry of European Integration. (2015). Annual Progress Report 2014 Albanian Contributution - Input I September 2013 - April 2014, 2 May.

Mitrushi, M. (n.d.). The role of the training on public administration human resource management. Available: http://www.westernbalkans.info/upload/docs/MiraMitrush_Albania.pdf

Olslzfski, D. \& Crrtchirz, D. A m. (2001). "Management Training and Development". In Golembiewski, R. T. (Ed.). Handbook of Orgational Behavior, second edition, revides and expanded. New York, Basel: Marcel Dekker, Inc.

Daniello, R. J. \& Laubsch, P. (2008). "Seniority versus Education: Resurrection of an Old Debate". In Scenarios in Public Administration: Critical Thinking Exercises. Maryland: University Press of America, Inc.

Organization for Economic Co-operation and Development. (1997). Public Service Training in OECD Countries, SIGMA Papers, 16, OECD Publishing. Available: $h$ http://dx.doi.org/10.1787/5kml619lizzn-en

United Nations Department of Economic and Social Affairs /International Association of Schools and Institutes of Administration. (2008). Standards of Excellence for Public Administration Education and Training. Available: http://unpan1.un.org/intradoc/groups/public/documents/un-dpadm/unpan034307.pdf 